\author{
Agata Kilar \\ http://orcid.org/0000-0002-2109-6385 \\ Kraków \\ aga311289@interia.pl \\ DOI: $10.35765 /$ pk.2021.3504.26
}

\title{
Groza postaci demonicznych Fiodora Dostojewskiego
}

\section{STRESZCZENIE}

Artykuł jest próbą syntetycznego ujęcia problemu grozy związanej z demonicznością niektórych bohaterów Dostojewskiego. Powieści Dostojewskiego to rozważania nie tylko na tematy filozoficzne, ale także teologiczne - poruszające tematykę wiary i niewiary w Boga. To również związane z nimi bogate spektrum demonicznego zła, budzącego przerażenie. Na podstawie powieści Bracia Karamazow i Biesy, a także opowiadania Bobok autorka zaprezentuje, jak rosyjski twórca wykorzystywał motywy demoniczne w swojej twórczości. Mamy więc tutaj zmarłych targanych wciąż ludzkimi namiętnościami, „,chorego na śmierć” Stawrogina, który jest personifikacją czystego zła, demonicznego Kiriłłowa, którego poglądy filozoficzne doprowadziły do samobójstwa, oraz Iwana Karamazowa jako Wielkiego Inkwizytora w Braciach Karamazow, którego zmorą jest diabeł. Na ich przykładzie autor Biesów przedstawił świat dążący do zagłady. Pokazał jednostki wyzbyte wyższych wartości moralnych, postaci odczłowieczone - demoniczne. Celem niniejszego artykułu jest pokazanie ich różnorodności demonicznej wyrażającej zło.

SŁOWA KLUCZE: literatura rosyjska, diabeł, groza, zło, postać demoniczna

\section{AB STRACT}

The Terror of the Demonic Figures of Fyodorf Dostoevsky

The article is an attempt to synthesize the problem of the horror associated with the demonicity of some of Dostoyevsky's characters. Dostoyevsky's novels are not only philosophical but also theological ones - touching the subject of faith and unbelief in God. It is also associated with a rich spectrum of demonic evil that is terrifying. Based on the novel The Brothers Karamazov and Demons, as well as the short story Bobok, the author will present how the Russian artist used demonic motifs in his work. So here we have the deceased, still tormented by human passions, "sick to death" Stavrogin, who is the personification of pure evil, demonic Kirillov, whose philosophical views led to suicide,

Sugerowane cytowanie: Kilar, A. (2021). Groza postaci demonicznych Fiodora Dostojewskiego. (c) (i) Perspektywy Kultury, 4(35), ss. 453-472. DOI: 10.35765/pk.2021.3504.26. 
and Ivan Karamazov as the Grand Inquisitor in The Brothers Karamazov, whose nightmare is the devil. On their example, the author of Demons presented the world striving for extermination. He showed individuals devoid of higher moral values, dehumanized figures - demonic. The purpose of this article is to show their demonic diversity expressing evil.

KEYWORD S : russian literature, devil, horror, evil, demon character

Biesy kręcą się, szalone,

Jako liście w słotny dzień.

Skąd ich tyle? Dokąd pędzą,

Zawodzące straszną pieśń?

Czy to czart się żeni z jędzą?

Czy ubożę zmarło gdzieś?

(Puszkin, 1982, s. 312)

A pasło się tam na górze stado wielu wieprzów. I prosili go, by im dozwolił wejść w nie i zezwolił im. Wyszły tedy duchy nieczyste z człowieka i weszły w wieprze. A stado pędem z urwistego brzegu wpadło do morza i potonęło. Widząc zaś pasterze, co się stało, uciekli i rozgłosili to po mieście i wioskach. I wyszli oglądać, co się stało. I przyszli do Jezusa, i ujrzeli, że człowiek, z którego wyszły czarty, siedział odziany i przy zdrowych zmysłach u nóg jego. I zdjął ich lęk. A ci, co widzieli, opowiedzieli im, jak uzdrowiony został od czartów.

(Łk VIII, 32-35)

Motywy demonologiczne w twórczości Fiodora Dostojewskiego odgrywały bardzo ważną rolę. W jego powieściach czytelnik niejednokrotnie styka się z wywołującymi grozę postaciami, które mają w sobie coś z demonów z rosyjskiego folkloru. Wiara w demony, obecna także w religiach chrześcijańskich, stanowi bowiem nieodłączną część kultury.

Postacie demoniczno-fantastyczne fascynowały twórców wielu epok literackich. Po raz pierwszy wizerunek Szatana pojawia się w Biblii, gdzie pod postacią węża skusił Ewę do zerwania owocu z drzewa poznania. W średniowieczu motywy demonologiczne najpełniej zostały zrealizowane w Boskiej komedii Dantego. To właśnie w tym arcydziele literatury światowej włoski poeta i filozof zaprezentował swoją wizję piekła, przedstawiając to, co zniekształcone i brzydkie. Pisarze doby renesansu również wykorzystywali w swojej twórczości motyw Szatana. Za przykład może posłużyć Sonet IV O wojnie naszej, która wiedziemy z szatanem, światem $i$ ciatem autorstwa Mikołaja Sępa-Szarzyńskiego. Poeta dowodzi, że 
ludzkie życie to nieustająca walka, w której największym przeciwnikiem człowieka jest Szatan, a jedyną drogą ratunku jest Bóg. Innym twórcą renesansowym, w którego twórczości pojawiają się elementy demonizmu, był William Shakespeare. Zło w dramacie angielskiego poety widoczne jest już w początkowych scenach utworu i ukazane jest pod postacią czarownic, które wnoszą do dramatu nastrój grozy i niepokoju. To wiedźmy kierują losem człowieka i kuszą głównego bohatera wizją szczęścia, ostatecznie doprowadzając go do klęski. W baroku motywy demonologiczne widoczne są nade wszystko w dziele Johna Milla Raj utracony. To utwór, w którym postać diabła ukazana została w nieco inny, niż dotychczas, sposób. To istota podobna do człowieka (bez rogów i szponów): targana przez wielkie namiętności, pełna godności, cierpiąca z powodu własnego upadku. Romantyzm to epoka, która fascynowała się tym, co nadprzyrodzone, fantastyczne, demoniczne, dlatego też utwory literackie epoki obfitują w wątki demoniczne. Najciekawsze realizacje tego motywu możemy odnaleźć w twórczości Johanna Wolfganga Goethego (Faust - tytułowy bohater, podpisuje pakt z diabłem własną krwią), Adama Mickiewicza (Pani Twardowska - podobny jak w Fauście motyw paktu z diabłem, Dziady cz. III - Szatan walczy o duszę Konrada, podpowiada bohaterowi bluźnierstwo), Juliusza Słowackiego (Kordian - siły nieczyste pomagające Szatanowi w tworzeniu przywódców powstania listopadowego). W późniejszej literaturze XIX w. motywy demonologiczne pojawiają się m.in. w twórczości autora Zbrodni $i$ kary ${ }^{1}$. Jego powieści to rozważania na tematy nie tylko filozoficzne, ale także teologiczne - poruszające tematykę wiary i niewiary w Boga. To również związane z nimi bogate spektrum demonicznego zła, budzącego przerażenie. Dostojewski w swoich utworach pokazuje postaci, które na drodze własnego wyboru odwróciły się od Boga. Odejście od Stwórcy, zdaniem pisarza, stało się przyczyną narodzin zła, a człowiek, skupiony wyłącznie na sobie, ulegał coraz większej dehumanizacji. Powody takiego stanu rzeczy należało upatrywać, zdaniem pisarza, w cywilizacji:

Ten stan, w którym zbiorowość rozpada się na jednostki, inaczej cywilizacja, jest stanem chorobowym. Utrata żywej idei Boga o tym świadczy. Drugi dowód, że jest to choroba, to ten, że człowiek w tym stanie czuje się źle, tęskni, traci źródło prawdziwego życia, nie ma bezpośrednich doznań, i wtedy na wszystko wyraża zgodę (Dostojewski, 1979, s. 43).

1 Na temat motywów demonologicznych w literaturze rosyjskiej patrz: Kowalczyk i Orłowska, 2004. 
Postępujący rozwój cywilizacji sprawił, że ludzie zapomnieli o podstawowych wartościach chrześcijańskich: dobru, sprawiedliwości, miłości bliźniego, a skupili się wyłącznie na swoich potrzebach. Dostojewski dodaje, że: „Wszelka cywilizacja zaczyna się od rozpusty” (Dostojewski, 1979, s. 156). Bohaterowie analizowanych poniżej utworów: Biesów, Braci Karamazow, opowiadania Bobok, nieustanie zmagają się z siłami demonicznymi. Interpretacja poszczególnych utworów pozwoliła stworzyć obraz człowieka narażonego na działanie mocy inferalnych oraz ukazać jego zmagania z nimi. To walka, z której żaden z bohaterów Dostojewskiego nie wychodzi zwycięsko ${ }^{2}$.

Rozważania na temat grozy postaci demonicznych w utworach rosyjskiego pisarza rozpoczniemy od analizy Biesów. To polifoniczna powieść antyutopijna, będąca studium na temat ideologii socjalizmu, obraz fermentu duchowego i ideowego epoki, a zarazem głęboka analiza kondycji ówczesnego człowieka i diagnoza życia w Rosji drugiej połowy XIX w. (Krasucka, 2011). Już sam tytuł powieści wskazuje na związki z demonologią i folklorem rosyjskim³ ${ }^{3}$ Urška Zabukovec zauważa, że: „Dostojewski, kreując własną wizję demonologii w omawianej powieści, czerpał z wielu źródeł - odwoływał się do motywów średniowiecznej literatury rosyjskiej i europejskiej oraz rosyjskiej literatury romantycznej" (Zabukovec, 2013). W Biesach możemy odnaleźć wiele takich folklorystycznych motywów, a większość z nich wiąże się z bohaterami powieści: ich wyglądem zewnętrznym i zachowaniem.

Głównymi przedstawicielami sił demonicznych w powieści są: Stawrogin, Piotr Wierchowieński i Kiriłłow. Trzej mężczyźni reprezentujący

2 Dostojewskiego, jako twórcę, interesowała w szczególności prawdziwa natura człowieka. $\mathrm{W}$ swoich utworach sięgał on przede wszystkim po tematy związane z codziennym życiem mieszkańców Petersburga, które czerpał z gazet, kronik kryminalnych i własnych doświadczeń. Jego bohaterowie to ludzie targani wielkimi namiętnościami, przeklętymi problemami, jak określa je Przybylski, a także wątpiący w Boga i Jego naukę. W swoich utworach pisarz pokazuje ludzi, którzy nie są tylko dobrzy lub tylko źli. To jednostki uwikłane w przeróżne spory, nękane wątpliwościami natury egzystencjalnej oraz poszukujące odpowiedzi na dręczące je pytania. Niejednokrotnie jego bohaterowie posiadają cechy, które wzbudzają w ich otoczeniu grozę i niepokój. Podkreśla to ich wyjątkowość i wewnętrzne rozdarcie, które czyni je w pewnym stopniu bohaterami demonicznymi. Dostojewski, który z kategorii piękna uczynił prawdę fundamentalną, doskonale zdaje sobie sprawę, że może być ono zwodnicze (jego demoniczni bohaterowie są przeważnie młodzi i atrakcyjni fizycznie). Zatem człowieka, który dla pisarza jest niepoznawalną zagadką, nie można określić jednoznacznie dobrym lub złym. Dlatego też niektórzy jego bohaterowie to indywidua pełne sprzeczności, które wzbudzają w czytelnikach grozę swoim zachowaniem. Na temat prawdziwej natury człowieka i kategorii piękna jako fundamentalnej prawdy dla Dostojewskiego patrz: Perkowska, 2006, s. 103-114.

3 Słowo „bies” w pojęciu religijnym to ,zły duch”, natomiast w wierzeniach ludowych jest to tzw. siła nieczysta. Zob. Leatherbarrow, 2005, s. 14. Co do folkloru, to po przyjęciu chrześcijaństwa bardzo często słowiańskie bóstwa uważano za biesy, diabły, demony. Zob. Lotman, 2002, s. 93. 
odmienne światopoglądy, których łączył jeden cel - służba nowożytnym ideom, do których Dostojewski zalicza materializm ateistyczny Ludwika Feuerbacha i europejskie doktryny socjalizmu. Główną postacią demoniczną, wzbudzającą największą grozę, jest Mikołaj Wsiewołodowicz Stawrogin. To niezwykle piękny młodzieniec, którego uroda nie tyle zachwyca, ile wprawia w konsternację. Jego twarz sprawia wrażenie maski:

Był to człowiek bardzo przystojny, lat chyba dwudziestu pięciu. (...) Był ubrany elegancko, a zachowywał się z finezją człowieka wychowanego po wielkopańsku. (...) Nie był zbyt rozmowny, uprzejmość jego pozbawiona była sztuczności, niezwykle skromny, a jednocześnie śmiały i pewny siebie jak nikt (...): włosy miał jak gdyby zanadto czarne, jasne oczy jakoś zanadto spokojne i świetliste, cerę zanadto delikatną, rumieniec zbyt częsty i silny, zęby jak perły, wargi koralowe. Chłopiec jak malowany, a jednocześnie dziwnie jakoś odrażający. Mówiono, że twarz jego przypomina maskę (...)! Wzrost miał średni (Dostojewski, 2015, s. 45).

Opis twarzy Stawrogina wywołuje w ludziach przebywających w jego otoczeniu niepokój. Piękno bowiem, jak zauważa Cezary Wodziński, wzbudza strach i sieje zniszczenie nie gorzej niż zło (Wodziński, 2018). Dostojewski natomiast w swoich zapiskach odnotowuje, że: „Przyszły Antychryst będzie mamił pięknem” (Dostojewski, 1976, s. 484). Potwierdza to tezę, że Stawrogin to wcielenie zła. Przez to jego diaboliczna postać jest pełna grozy. Wodziński notuje:

Piękno pokazuje się złowieszczo, jest przerażające, straszliwe, nieokreślone, tajemnicze, kryjąc w sobie zarazem pozytywne negatywy tych określeń (Wodziński, 2018, s. 57).

Emocje, jakie Mikołaj Wsiewołodowicz swoim wyglądem budzi w otoczeniu, świadczą o demonizmie postaci. Jednym z przejawów siły nieczystej w osobie Stawrogina jest jego twarz, która wygląda jak maska. William J. Leatherbarrow w książce $A$ Devil's Vaudeville. The Demonic in Dostoevsky's Major Fiction zauważa, że w nauczaniu średniowiecznej Cerkwi bardzo mocno akcentowano demoniczny status maski (Leatherbarrow, 2005). Natomiast Zabukovec pisze:

Maskowanie ma na celu nie tylko dławienie czy tłamszenie uczuć, ukrywanie prawdziwego oblicza (każdy krąg kulturowy posiada swoisty styl panowania nad reakcjami emocjonalnymi), lecz jest przede wszystkim manipulowaniem i kontrolą (Zabukovec, 2013, s. 187). 
Potwierdzenie słów Zabukovec czytelnik znajdzie w powieści. Dostojewski, opisując osobę Stawrogina, wspomina, że wzbudza on wielkie zainteresowanie wśród mieszkańców Skworesznik, a niektórzy wręcz sądzą, że skrywa on w duszy mroczną tajemnicę. Niestety jego twarz nieruchoma maska - nie zdradza żadnych uczuć i trudno odgadnąć, co naprawdę czuje i myśli główny bohater Biesów. Sam Dostojewski w rozmowach ze swoim przyjacielem, doktorem Stiepanem Janowskim, niejednokrotnie wspominał: „Mam swojego Mefistofelesa” (Łużny, 1984, s. 58). Michalska-Suchanek pisze, że:

emanował wewnętrznym chłodem. Był wyniosły, dumny, w stosunku do otoczenia lekceważący, cyniczny, bezwzględny i szyderczy. Istotę jego egzystencji wyznaczała całkowita obojętność wobec otaczającej go rzeczywistości, a działania określała postawa wszechnegacji i wszechignorancji (Michalska-Suchanek, 2015, s. 123).

Obojętność i ignorancja Stawrogina doprowadziły go do nienawiści wobec własnej osoby, a także, jak zauważa Raźny, do negacji własnego statusu ontycznego, niezgody na własne istnienie, co w ostateczności skłoniło go do samobójstwa (Raźny, 2004). Zanim jednak popadł w „chorobę na śmierć” - jak określa Søren Kierkagaard brak nadziei na inne życie i na akceptację własnego ja - fascynował się nowożytnymi ideami zachodnimi, które przekazywał swoim przyjaciołom. Uwiódł ich nimi w demoniczny sposób - budząc jednocześnie strach i uwielbienie. Sam zaś wypalił się wewnętrznie, utracił sens i cel życia, w którym pozostawał jak w letargu. Był niczym kukła. Paul Jewdokimow określił jego osobę jako: „ciało [które - A.K.] nieustannie wlecze za sobą trupa własnego ducha” (Evdokimov, 2002, s. 265).

Powracając do kwestii maski i wiążącej się z nią demoniczności Mikołaja Wsiewołodowicza, należy podkreślić, że potrafił on tak zapanować nad własnym ciałem, że nawet we śnie wyglądał jak woskowa figura:

Zdziwiło ją, że mógł zasnąć tak szybko i że może spać, siedząc tak prosto i nieruchomo. Nawet oddech trudno było zauważyć. Śpiący miał twarz bladą, na pół zastygłą, martwą. Miał brwi zsunięte i nachmurzone. Przypominał bezduszną figurę woskową (Dostojewski, 2015, s. 225).

Jego umiejętność wprowadzania się w stan letargu była niepokojąca, potrafił bowiem zapanować nad biologicznymi funkcjami ciała, co było wręcz nieludzkie, podkreśla to Michalska-Suchanek: „Kontrolując własną cielesność, zamieniał się w potwora, demona” (Michalska-Suchanek, 2015, s. 134). Maska, którą nosi Stawrogin, jest zatem nieodłączną częścią jego 
osobowości i jak stwierdza Bierdiajew - jest on duchowo martwy (Bierdiajew, 2002). Idee, którymi uwodził swoich przyjaciół, żyją jednak nadal w ich świadomości, stając się jej przekleństwem. Pod ich wpływem tytułowi bohaterowie powieści - nade wszystko Piotr Wierchowieński oraz Kiriłłow, a w jakimś stopniu Szatow, ulegają depersonalizacji. Jest to depersonalizacja demoniczna, taka sama, jakiej podlega Iwan Karamazow w ostatniej powieści F. Dostojewskiego Bracia Karamazow. Rzuca się w oczy każdemu czytelnikowi, gdyż wskazuje na nią sam autor poprzez tytuł powieści oraz dwuczłonowe motto: cytat $\mathrm{z}$ wiersza Aleksandra Puszkina pt. Biesy oraz fragment Ewangelii według św. Łukasza (VIII, 32-36), mówiący o uzdrowieniu przez Chrystusa człowieka opętanego. Demoniczność bohaterów tej powieści jest zatem oczywista, podkreślana nie tylko w filologicznych i kulturoznawczych opracowaniach, ale także w esejach literackich czy publicystycznych, czego przykładem może być wypowiedź Bronisława Wildsteina na temat Stawrogina:

To on wprawia w ruch poszczególne postacie powieści, budzi w nich pragnienia, (...) ukierunkowuje je w określony sposób, nadaje kształty drzemiącym w nich impulsom, modeluje kolejne osobowości w prawie nowe kształty. Jest do pewnego stopnia ich stworzycielem. Nie może być Bogiem, staje się więc antychrystem. Jest jednak tylko człowiekiem, nie do końca więc potrafi być świadomy swej roli (Wildstein, 2015, s. 158).

Z przytoczonych powyżej wypowiedzi różnych autorów wypływa jednoznaczny wniosek - Mikołaj Wsiewołodowicz to postać demoniczna, beznamiętnie manipulująca innymi. Nie ulega wątpliwości, że budzi ona strach, wprowadza w życie mieszkańców Skworesznik grozę, która nie rzuca się jednak w oczy tak jak jego demoniczność

O grozie postaci Stawrogina i jej demonicznych inklinacjach świadczy też jego „spowiedź” u starca Tichona. To właśnie wtedy, wydawałoby się, powinien odrzucić maskę i szczerze wyznać swoje grzechy. On natomiast postępuje wręcz przeciwnie. Mimo iż szczerze, a nawet ekshibicjonistycznie - jak zauważa Dariusz Jastrząb - spowiada się ze swoich win, to jego spowiedź nie jest prawdziwa, nie jest szczera; jest kreacją artystyczną, która ma szokować spowiednika i ewentualnie czytelnika po zaplanowanym jej upublicznieniu. Jak pisze Zabukovec:

Nie stanowi ona odsłonięcia prawdziwego Ja w odniesieniu do ukrywającej go maski-twarzy, lecz przeciwnie - autobiografia (...) jako estetyzacja własnego życia stanowi próbę maskowania siebie (...), próbę autokreacji według własnych kryteriów (...). Gest samostwarzania to gest demoniczny, gest Szatana. Stoi on w sprzeczności z pokorą czy skruchą (Zabukovec, 2013, s. 189). 
W wyznaniu Stawrogina brakuje prawdy. To spowiedź pełna zakłamania, pomimo iż, paradoksalnie, mówił on samą prawdę. Raźny uważa, że:

Pokusy demoniczne zamknęły nad nim niebo i skazały go na rozpacz. Nie uwolni go od niej spowiedź przed Tichonem, gdyż jest dyktowana panującą w jego świadomości pychą (Raźny, 2004, s. 136).

I dalej:

Paradoks Stawrogina nie polega na tym, że nie wierzy, ale na tym, że wierząc w szatana, nie wierzy w Boga. Jego ateizm nie jest absolutny, o czym się upewnia w rozmowie $\mathrm{z}$ Tichonem. Wynika z obojętności na Boga, z letniego serca, (...). Rozpacz letniego serca jest rozpaczą metafizyczną (Raźny, 2004, s. 137).

Pogląd ten podziela Jastrząb, który pisze:

Artykulacja grzesznych faktów podczas spowiedzi niekoniecznie świadczy o religijnym charakterze samego wyznania. (...) może być ona substytutem nieobecnej w człowieku żywej wiary w Boga (Jastrząb, 2017, s. 139).

Dlatego Tichon przeraził się Stawrogina, poraził go dominujący w nim absolutny brak poczucia winy za grzech pedofilii, któremu towarzyszyła nieludzka pogarda wobec jego ofiary - niepełnoletniej córki gospodyni domu. Dramat Stawrogina polegał na tym, że nie postrzegał świata w kategoriach dobra i zła. Idea Sodomy i postać Madonny fascynowały go w tym samym stopniu. Jedno i drugie, jak zauważa Bierdiajew, było dla niego tak samo atrakcyjne (Bierdiajew, 2004). Sięgnął dna piekieł, odrzucił Boga i wszystkie wartości chrześcijańskie. Z tego punktu widzenia rację ma Nikołaj Łosskij, pisząc:

Dla tego, kto utracił Boga i zagubił zdolność do indywidualnej miłości, cały system wartości rozpada się na oddzielne elementy i normalne stopnie wartości przestają dla człowieka istnieć. Jednostka ludzka, przeżywająca taką katastrofę, znajduje się w sytuacji tym niebezpieczniejszej, im szczodrzej jest obdarowana duchowo i im większą siłę posiada. W rzeczy samej, taki człowiek nieuchronnie wstępuje na drogę ryzykownych doświadczeń i fantastycznych przedsięwzięć (Łosskij, 1953, s. 237).

Powoli, ale konsekwentnie, wyzbywał się człowieczeństwa, a jego bunt przeciwko transcendencji znalazł ostatecznie finał w samobójstwie bohatera Dostojewskiego. 
Kolejną postacią demoniczną w powieści jest Piotr Stiepanowicz Wierchowieński - „personifikacja pędu niespokojnego ducha”, jak określa go Dariusz Jastrząb (2017, s. 136). Młodego Wierchowieńskiego poznajemy w początkowych rozdziałach utworu. Już sam opis postaci wskazuje na jej demoniczny charakter:

Był to młodzieniec w wieku mniej więcej dwudziestu siedmiu lat, dość wysoki, o rzadkich, długich blond włosach i o ledwo widocznej brodzie i wąsach. Był ubrany modnie, lecz nie przesadnie; na pierwszy rzut oka wydawał się przygarbiony i niezgrabny, chociaż $\mathrm{w}$ istocie nie był przygarbiony (...). Trudno powiedzieć, że był brzydki, a jednak twarz jego nie mogła się podobać nikomu. Głowę miał wydłużoną z tyłu i ściśniętą z boków, tak, że rysy twarzy wydawały się wyostrzone; czoło wysokie a wąskie, lecz rysy twarzy drobne; oko bystre, nos mały i spiczasty, wargi długie i wąskie; wyraz twarzy jak gdyby chorobliwy, lecz tylko pozornie. Na policzkach i koło uszu widać było jakąś fałdę, która sprawiała wrażenie, jak gdyby był rekonwalescentem po ciężkiej chorobie. A jednak był zupełnie zdrów i silny, nawet nigdy nie chorował (Dostojewski, 2015, s. 178-179).

Był to człowiek o twarzy pełnej sprzeczności i nieokreśloności ${ }^{4}$. Zabukovec zwraca uwagę, że świadczy to o demonizmie postaci Wierchowieńskiego, bowiem wszystkie niedookreślenia zastosowane przez Dostojewskiego akcentują nieuchwytność, ulotność jego obrazu (Zabukovec, 2013, s. 189). Przede wszystkim niemożność jego pozytywnego opisu. To emanacja zła tkwiącego w Stawroginie - jego piękno - jak pisze Krasucka (2011, s. 95): „nie jest tożsame z dobrem, lecz skrywa zło”. Natomiast dalszy opis postaci Wierchowieńskiego w Biesach łatwo można przyrównać do biblijnego węża:

Mówił szybko, a jednocześnie płynnie (...). Myśli jego, chociaż z pozoru zawiłe, były jednak zimne i zdecydowane. (...) Słowa jego robiły wrażenie gładkich, dużych paciorków, sypiących się równo, zebranych w porę i zawsze już naprzód przygotowanych. $Z$ początku mogło się to nawet podobać. Po chwili jednak stawało się wstrętne (...). Zaczynało się wydawać, że ma w ustach język inny niż wszyscy, niezwykle długi i wąski, strasznie czerwony, o długim koniuszku, kręcącym się bezwiednie i nieustannie (Dostojewski, 2015, s. 179).

Nietrudno się domyślić, że Wierchowieński został tu przedstawiony jako kłamca i kusiciel, którego głównym narzędziem jest język i wypowiadane

4 W folklorze takie niejednoznaczne i niewyraźne rysy twarzy traktowane były jako oznaki demoniczności. Zob. Williams, 2008, s. 96. 
przy jego użyciu słowa. Za jego przyczyną doprowadza mieszkańców Skworesznik do zguby. To właśnie język stanowi jego oręż. Zabukovec pisze: „Istotą Piotra jest właśnie amorficzność, zdolność wcielania się w różne role, umiejętność dostosowywania się do oczekiwań, pragnień, fantazmatów innych (...). Piotr, gdy odgrywa rolę, jest sobą" (Zabukovec, 2013, s. 190). Podobnie jak Stawrogin, Wierchowieński odrzucił wszelkie pozytywne relacje z ludźmi, przestał kierować się chrześcijańskimi wartościami i postanowił żyć wedle idei, które przywiodły go na drogę duchowego odosobnienia. W swoim postępowaniu nie był ukierunkowany na dobro. Wartości, którymi się kierował, organizując rewolucyjną „piątkę” na rosyjskiej prowincji, nie tylko godziły w dobro osoby ludzkiej i ludzkiej społeczności, ale równiė̇ w jego metafizyczny wymiar ${ }^{5}$. Pietrusza przestał o nie zabiegać. Wolał skupić się na przekazanej mu przez Stawrogina niszczącej wszystko idei rewolucji - w imię socjalizmu. Służąc tej idei, stał się uosobieniem jej destrukcyjnego zła. Dodatkowym przejawem demoniczności postaci Piotra Stiepanowicza jest jego obżarstwo i ogólny stosunek do jedzenia. Chociaż nie jest to wyłączny atrybut Szatana, jednak w niektórych okolicznościach, podczas spożywania przez Piotra posiłków, można odnieść wrażenie, że przyjmuje on rolę kusiciela ${ }^{6}$.

5 „Wartość, najkrócej mówiąc, jest rozpoznaniem bytu jako dobra dla nas. A dokładniej mówiąc, to dobro dla nas jest podstawą uznania czegoś za wartość (...). Cenna jest dla nas relacja z tym bytem, którego skutki są dobrem dla mnie. Jeżeli tak jest, to trzeba zabiegać o trwanie relacji z bytem, który jest dobrem dla mnie”. Zob. Gogacz, 1998, s. 95.

6 Sceny posiłków u Karmazinowa, Kiriłłowa czy Liputina. W szczególności obiad jedzony przez Wierchowieńskiego w restauracji w obecności Liputina posiada znamiona sceny kuszenia. Piotr Wierchowieński podobnie jak biblijny wąż kusi swoich rozmówców i namawia do popełniania niegodziwych czynów. Wykorzystuje do tego posiłki, które spożywa w ich obecności. Zachęca interlokutorów do wspólnego jedzenia, jednocześnie kusząc i namawiając do zła. Badaczka w swoich wywodach podkreśla, że obżarstwo, chociaż jest charakterystyczne dla człowieka, nabiera szczególnego znaczenia, ponieważ Piotr Wierchowieński spożywa posiłki podczas niezwykle dla niego ważnych rozmów. Według Urški Zabukovec nabiera to wręcz symbolicznego znaczenia i dlatego też przypomina to szatańskie kuszenie (Zabukovec, 2013, s. 190-191). Urška Zabukovec podobny motyw zauważa w Braciach Karamazow w scenie rozmowy Iwana z Aloszą w restauracji, kiedy to starszy z braci częstuje młodszego zupą rybną i słodkościami. Badaczka zauważa, że gest ten został niejako zapoczątkowany przez Smierdiakowa - inicjatora tragicznych zdarzeń w powieści: „Smierdiakow, wysyłając Aloszę w objęcia Iwana, wystąpił w roli jego sługi, poplecznika. Od tego momentu dla Aloszy zaczyna się walka z diabelskimi podszeptami. Gdy Alosza wszedł do knajpy, Iwan najpierw zaprosił go na obiad - zupę rybną, herbatę i wiśniowe konfitury. (...) Zupa rybna jest nośnikiem diabelskiej, zniewalającej energii, którą Iwan teraz chce zatruć Aloszę. Spożycie tej zupy w ujęciu symbolicznym ma takie konsekwencje, jak spożycie zakazanego owocu (...)” (Zabukovec, 2011, s. 384-385). Autorka w cytowanym artykule szczegółowo omawia, na czym polega diaboliczność sceny w knajpie. 
Kolejnym demonicznym bohaterem Biesów, budzącym w czytelnikach grozę głoszonymi poglądami, jest Kiriłłow. To młody, około dwudziestosiedmioletni inżynier budowlany: „przyzwoicie ubrany, zgrabny i szczupły. Brunet, o twarzy bladej, cerze niezupełnie gładkiej, o oczach czarnych, matowych” (Dostojewski, 2015, s. 93). Na kartach powieści kilkakrotnie pojawia się odwołanie do czarnych, martwych oczu Kiriłłowa. Świadczyć to może o pustce, jaka w nim drzemie. W zestawieniu z bladą twarzą cała postać młodego inżyniera kojarzy się z chorobą i brakiem życia. Według Grzegorza Przebindy jest on:

Najbardziej demonicznym bohaterem „Biesów” (...). Twórcą planu prometejskiego samobójstwa, które ma zapewnić powszechną ziemską nieśmiertelność (Przebinda, dostęp: 04.03.2021).

Męczony depresją i obsesyjnymi myślami samobójczymi poświęcił się głoszonej przez Ludwika Feuerbacha koncepcji człowieka-boga. Zaprzeczając istnieniu Boga, który - według niego - nie dał ludziom nieśmiertelności, sam postanowił zająć jego miejsce, a raczej osiągnąć jego status poprzez pokonanie śmierci na drodze samobójstwa: „Jeżeli Bóg jest, to cała wola Jego i wyjść poza tę wolę nie mogę. Jeżeli nie ma, to wola jest moja i mam obowiązek ją wypełnić" (Dostojewski, 2015, s. 609). Aby tego dokonać, postanowił pokonać śmierć. W sposób wolny wybrał jej moment, a także formę - akt samobójczy. Pozbawił się życia wyłącznie po to, aby zmienić swój status istnienia $\mathrm{z}$ ludzkiego na boski. Wierzył jednocześnie, że jego czyn otworzy ludzkości - zgodnie z sugestią Feuerbacha - drogę do nowej fazy bycia - nieśmiertelności, uzyskanej wysiłkiem człowieka. Jak pisze Przebinda:

Prometeusz Dostojewskiego był przekonany, że śmierć nie ma obiektywnych przesłanek, lecz istnieje wyłącznie dlatego, iż ludzie się jej boją. Aby zniszczyć śmierć, wystarczy zabić strach przed nią. Dlatego właśnie Kiriłłow zaplanował i wykonał akt eschatologicznego samobójstwa, które miało być tragicznym wstępem do nowego życia.

Nie napawa ono ani optymizmem, ani nadzieją na nieśmiertelność Kiriłłowa poza transcendencją. Samo wyjście śmierci naprzeciw nie oznacza jej pokonania. Nie zawiera w sobie także mocy wskrzeszającej Kiriłłowa po samobójstwie. Ma ono wymiar jedynie eksperymentalnego samounicestwienia inspirowanego „utopią metafizyczną” - jaką się jawi urzeczywistnienie proponowanej przez Feuerbacha ateistycznej deifikacji. Nieistnienie, na które skazuje się Kiriłłow w akcie samobójstwa, jest świadectwem uzależnienia od siły, która w pewnym sensie kieruje jego wolą. 
Dostojewski obdarzył go bowiem pozytywnymi odruchami wskazującymi na żywą więź z ludźmi i ze światem. Był lubiany przez dzieci, potrafił być pomocny i wrażliwy na ludzkie cierpienie, zapalał lampkę przed ikoną, zachwycał się pięknem przyrody. Te więzy z życiem zdominowała jednak w jego świadomości ciemna siła popychająca go ku śmierci. Niestety - zaznacza Michalska-Suchanek - „zwyciężyła mroczna część osobowości Kiryłłowa, a myśli o własnej boskości i metafizycznej wolności powoli doprowadzały go (...) aż na przedmieścia psychozy” (Michalska-Suchanek, 2015, s. 157). Aleksy Niłycz odrzucił Boga, jego życie i postępowanie nie miało żadnego punktu odniesienia, niczego, co mogłoby to życie wartościować. Żył w aksjologicznej próżni. Nic go nie ograniczało, czuł się niezwyciężony. Opanowany przez demona władzy nad śmiercią, za atrybut swojej boskości uznał wolną wolę. Michalska-Suchanek (2015, s. 166) pisze:

Samobójstwo stało się w idei Kiryłłowa pojęciem kluczowym. Dowieść miał w ten sposób osiągnięcia wolności absolutnej, w konsekwencji stać się panem swojej śmierci, człowiekiem-bogiem. (...) Śmierć stanowi gest finalny $(. .$.$) procesu pokonywania tanatycznego lęku, przezwyciężania$ upokarzającej paniki własnego ciała, wynikającej z podporządkowania człowieka naturze.

Dokonując tego aktu, Kiriłłow potwierdzał swoje zwycięstwo nad śmiercią i udowadniał, że Bóg nie istnieje. Uważał, że dzięki samobójstwu uwalnia się od wszelkich praw rządzących człowiekiem - zamierzał przezwyciężyć instynkt samozachowawczy, który dąży do ochrony życia - tym samym dowodząc słuszności swoich poglądów na temat Boga. Moment samego samobójstwa to, jak uważa Enza Paci, kwintesencja demonizmu (Paci, 1980, s. 275). Kiriłłow w tym momencie zaczyna przejawiać zwierzęce odruchy:

coś zawyło w pokoju i podbiegło ku niemu. (...) Przy ścianie na wprost okna, na prawo od drzwi, stała szafa. Z prawej strony, w kącie między szafą i ścianą, stał Kiriłłow. Stał jakoś okropnie dziwacznie. Nieruchomy, wyciągnięty, z opuszczonymi rękami wzdłuż tułowia, głową podniesioną i przytuloną do ściany. (...) Piotr Stiepanowicz stał trochę na ukos (...). Uderzyło go to przede wszystkim, że pomimo jego krzyku i rozpędu postać nie ruszyła się, nie drgnęła nawet, jak kamienna lub woskowa figura. Bladość twarzy była niezwykła, czarne oczy - nieruchomo wpatrzone w jakiś punkt. (...) Wierchowieński poczuł gwałtowny ból w małym palcu lewej ręki. (...) [Kiriłłow - A.K.] wczepił się w niego i ściskał mu palec zębami (Dostojewski, 2015, s. 615-617). 
Zachowanie przyszłego samobójcy nabiera cech zwierzęcych. Jego postać ulega depersonalizacji, odczłowieczeniu, zezwierzęceniu. Świadczy o tym chociażby fakt, że Aleksy Niłycz gryzie Wierchowieńskiego w palec, chowa się po kątach jak wystraszone zwierzę, wydaje dziwne, piskliwe dźwięki. Strach i wściekłość, które opanowały w tym momencie „Prometeusza Dostojewskiego”, jak nazywa go Przebinda, przydały mu zwierzęco-diabolicznego charakteru (Michalska-Suchanek, 2015). W takim stanie zostawia go przerażony Piotr Wierchowieński, który czeka na jego samobójczą śmierć, gdyż Kiriłłow bierze na siebie zlecone przez niego zabójstwo Szatowa - zbuntowanego członka rewolucyjnej piątki. Groza bijąca ze spotkania tych dwóch demonicznych bohaterów nie znika w momencie, gdy Wierchowieński, słysząc strzał rewolweru, wraca i stwierdza śmierć Aleksego Niłycza. Przerażający widok jego trupa potęguje jedynie strach przed siłą, która w okamgnieniu spustoszyła twarz i ciało młodego inżyniera, marzącego o statusie człowieka-boga.

Pośród bohaterów Dostojewskiego, wywołujących największe emocje u czytelników i badaczy, na uwagę zasługuje z całą pewnością Wielki Inkwizytor, w którego wciela się Iwan Karamazow - postać wzbudzająca największą grozę spośród wszystkich bohaterów Braci Karamazow. Dostojewski ustami Iwana opowiada fikcyjną historię Wielkiego Inkwizytora, której sedno stanowią religijne i polityczne pytania o wolność, poddaństwo, tajemnicę i autorytet. Legenda o Wielkim Inkwizytorze to według Evdokimova „synteza wszystkich idei religijnych” (Evdokimov, 1972, s. 95) pisarza $^{7}$. To poemat prozą, traktat filozoficzny o ponownym przyjściu Jezusa. Tytułowy Inkwizytor przekonuje, że ludzie nie są wystarczająco silni, aby podążać za Chrystusem i wypełniać Jego naukę. Wolą cieszyć się ziemskimi uciechami, niż zabiegać o królestwo niebieskie. On, jako orędownik szczęścia - a jednocześnie głosiciel królestwa Bożego na ziemi bez Boga - daje im tę możliwość. Jest nią idealny ustrój społeczny, jaki propagowali dziwiętnastowieczni teoretycy socjalizmu. Inkwizytor pozwala ludziom wybrać to, co według nich przyniesie im radość, jednocześnie proponując im socjalizm jako idealne rozwiązanie. Stwarza im pozory wolności - za Bierdiajewem możemy powtórzyć, że powodzenie nieprawego planu Inkwizytora wiąże się z problemem wolności, która u Dostojewskiego podlega dyskusji w jego powieści:

Zła nie da się wyjaśnić bez wolności. Zło pojawia się na drogach wolności. Bez tego związku z wolnością nie istnieje odpowiedzialność za zło. Bez wolności za zło odpowiadałby Bóg. Dostojewski głębiej niż ktokolwiek inny zrozumiał, że zło jest dzieckiem wolności. Rozumiał jednak

7 Podobne zdanie na ten temat miał Czesław Miłosz. Zob.: Miłosz, 1985, s. 58. 
także, że bez wolności nie ma dobra. Dobro jest także dzieckiem wolności. Wiąże się z tym tajemnica życia, tajemnica losu człowieka. Wolność jest irracjonalna i dlatego może tworzyć dobro oraz zło (Bierdiajew, 2004, s. 49).

Nadmierna wolność, jaką zdobył Inkwizytor, doprowadziła, do tego, że zaczął on ją wykorzystywać do własnych celów, nade wszystko zaś - przeciwko samemu Chrystusowi. Samowola, w którą przekształciła się wolność dana Inkwizytorowi, stała się źródłem nieprawości i zła (Grzmot-Bilski, 2016).

Wielki Inkwizytor traktowany jest jako wcielenie antychrysta ${ }^{8}$. To przeciwnik Chrystusa, który ponownie przyszedł na ziemię, aby zbawić ludzkość. Andrzej Penke uważa, że:

Mimo iż Wielki Inkwizytor czuje się poruszony milczeniem Chrystusa, jako Antychryst nie może nie skierować swoich oskarżeń pod Jego adresem. Najostrzejszym zarzutem skierowanym wobec Chrystusa jest obdarzenie człowieka darem wolności. (...) Zadaniem Inkwizytora jest uwolnienie człowieka od wszelkiej odpowiedzialności, poddając go bezwzględnemu i ślepemu posłuszeństwu temu, kto ma władzę w swoich rękach. W ten sposób przed człowiekiem otwiera się droga do nowego zbawienia (...). Antychryst zatem ukazuje siebie jako tego, który ma środek na rozwiązanie każdego problemu, lepiej niż to czyni Bóg (Penke, 2004, s. 136).

Powyższy cytat ukazuje podobieństwo Inkwizytora do Szatana z Pisma Świętego. Podobnie jak biblijny kusiciel Chrystusa, Wielki Inkwizytor kusi ludzi wizją łatwego szczęścia. Chce zbudować swoje królestwo na trzech pokusach, którym oparł się Chrystus (Grzmot-Bilski, 2016). Swoich zwolenników uwalnia od wątpliwości i wyrzutów sumienia. Jak pisze A. Penke (2004, s. 138): „W ten sposób Antychryst obarcza Chrystusa winą za przyniesienie miecza na ziemię, podczas gdy on - Antychryst - przychodzi jako zwiastun pokoju”. W poemacie Iwana Karamazowa postać Wielkiego Inkwizytora przedstawiona została jako orędownik pozytywnych ideałów, dlatego też należy go postrzegać jako fałszywego Chrystusa, a nie anty-Chrystusa (Paprocki, 2000). Jest on wytworem młodzieńczego buntu Iwana, hołdującego ideom socjalizmu (Augustyn, 2015). Groza postaci bohatera Legendy młodego Karamazowa polega na jego

8 Fragment Legendy o Wielkim Inkwizytorze doczekał się wielu interpretacji. Niektórzy badacze uważają, że Inkwizytor symbolizuje katolicyzm i papiestwo. Zob. Smaga, 2009, s. LXIILXXIII. Tadeusz Sucharski natomiast uważa, że Wielkim Inkwizytorem jest Rosja. Zob. T. Sucharski, 2002, s. 173-174. 
podobieństwie do Szatana. Jako Wielki Inkwizytor rozmawia on z Chrystusem na temat biblijnego kuszenia podczas czterdziestodniowego postu Jezusa na pustyni. Tłumaczy mu, na czym polegał Jego błąd - odrzucając propozycje Szatana, Chrystus pozbawił się władzy nad ludźmi. Dostojewski w Legendzie kładzie nacisk na bunt metafizyczny. Tyran - Inkwizytor, współczujący ludziom, zastąpił Boga i Jego Syna, dopuszczających cierpienie niewinnych dzieci. To personifikacja Szatana, która przybiera postać dobra, sedno antychrystowej pokusy.

Postać Iwana nabiera demonicznego charakteru również poza Legendą. W rozdziale „Diabeł. Zmora Iwana Fiodorowicza” bies zjawia się gorączkującemu autorowi Legendy. Nie opuszcza go, gdyż jawi się jako jego alter ego - mroczna strona osobowości, sobowtór. Diabeł zjawiający się Iwanowi wytwarza przerażającą energię, która rośnie z każdym jego słowem, choć wizerunek jego został karykaturalnie strywializowany:

Był to jakiś pan czy raczej rosyjski dżentelmen pewnego gatunku, nie pierwszej już młodości (...), z niezbyt jeszcze widoczną siwizną w ciemnych, dość długich i gęstych włosach i z siwiejącą bródką podstrzyżoną w szpic. Miał na sobie jakiś brązowy żakiet, najwyraźniej od lepszego krawca, ale już znoszony (...). Wszystko - (...) jak u każdego szyk dżentelmena, koszula (...) okazywała się przybrudzona, a szeroka szarfa porządnie wytarta. (...) Słowem, przyzwoite pozory mimo nader skromnych zasobów kieszeni (Dostojewski, 2009, s. 765).

Narrator ma tu na celu wyśmianie jego postaci, wskazanie na jej karykaturalną rolę i podkreślenie lekceważącego stosunku Iwana do własnego alter ego. Im mniej się on do niego przyznaje, tym bardziej diabeł staje się rzeczywisty. I na odwrót, im bardziej Iwan skłonny jest zaakceptować istnienie diabła, tym bardziej się on rozmywa w rzeczywistości.

Diabeł jako bohater powieści nie wydaje się postacią straszną. Wręcz przeciwnie, został przedstawiony w sposób karykaturalny, prześmiewczy - jako fałszywy inteligent. Wzbudza jednak pewną grozę. Czytelnik ma świadomość, że bies jest postacią wymyśloną przez chory umysł Iwana Karamazowa. Już sam ten fakt wzbudza niepokój. Diabeł próbuje wprost powiedzieć, kim jest, ale Iwan mu zabrania, nie dopuszcza do siebie myśli, że naprawdę rozmawia z Szatanem. Ostatecznie jednak ujawnia kim jest: „Szatan sum et nihil humanum a me alienum puto” (Dostojewski, 2009, s. 770) ${ }^{9}$. W teologii chrześcijańskiej - pisze Zabukovec - diabeł bardzo często zjawia się pod postacią przyjaciela, bliźniego, gości, „brata”, kobiety (Zabukovec, 2013). W tym przypadku pojawił się

9 „Jestem Szatanem i nic, co ludzkie, nie jest mi obce” (łac.). 
jako gość - prawdopodobnie z daleka. Podobnie jak w przypadku Stawrogina czy Wierchowieńskiego jego postać też jest w pewnym stopniu niedookreślona, co świadczy o demonicznym pochodzeniu.

Ostatnim utworem Fiodora Dostojewskiego, którego bohaterów zaliczyć należy do demonicznych, jest opowiadanie Bobok. Przedstawia ono ludzkie namiętności w świecie zmarłych. Akcja utworu rozgrywa się na cmentarzu, gdzie trafia sfrustrowany, przeżywający męki twórczej niemocy literat, Iwan Iwanowicz. Bohater szybko przekonuje się, że - wbrew powszechnemu wyobrażeniu - w miejscu kontemplacji, ciszy i ostatecznego spoczynku tętni życie. Ze zdumieniem zaczyna przyglądać się temu, co dzieje się wokół. Z obserwacji i podsłuchanych rozmów niezbicie wynika, że życie po śmierci to nie raj wypełniony spokojem i światłem, a rzeczywistość kipiąca całkowicie doczesnymi ambicjami, marzeniami, pragnieniami, ludzkimi wadami i zaletami, sympatiami i animozjami.

Zmarli w Boboku zdają sobie sprawę z tego, że nie żyją, jednak wciąż stawiają pytanie, co się $\mathrm{z}$ nimi dzieje. Mamy zatem zmarłych targanych wciąż ludzkimi namiętnościami, złudzeniami; istoty z fałszywymi gestami, udającymi życie. Postaci występujące w Boboku tworzą złożoną, niejednoznaczną rzeczywistość, w której nie wiadomo, co jest prawdą, a co ułudą. Są prawdziwe i nieprawdziwe jednocześnie, grają, udając grę, są lustrem dla siebie i bliźniaczo podobnym cieniem. Opowieść Dostojewskiego to „fantastyczny wytwór z pogranicza snu i jawy, symbolicznej wizji i groteski, makabry i schematu obyczajowego tkwi gdzieś obok, a rzecz polega na tym, by go wydobyć i pokazać światu” (Szkudlarek, dostęp: 08.03.2021). Ewa Szkudlarek w recenzji spektaklu Lifanova Bobok pisze:

scena na cmentarzu stanowi teatralne nawiązanie do ikonografii romantyzmu i problemu pozycji człowieka wobec niezmiennego losu, bezwzględnego czasu, nieuniknionej śmierci. Grobowce, sarkofagi wyrażają świadomość człowieka, który je wystawił, a nie tego, który w nich spoczął. Tylko żyjący zdaje sobie sprawę z kruchości własnego istnienia, wobec którego powinna być zachowana jakaś postawa moralna i etyczna. (...) W złośliwym chichocie twórców groteskowego danse macabre śmierć jest wyrokiem sprawiedliwości - traktuje wszystkich jednakowo - ubogiego pisarza i bogatego urzędnika. Martwota i rozkład ciała przypominają o wyrównaniu kondycji ludzkiej po śmierci. Narodziny są początkiem drogi ku śmierci, życie wychodzi z ziemi i do niej powraca. Matka-Ziemia rodzi, ale i przyjmuje zmarłych (Szkudlarek, dostęp: 8.03.2021).

Świat ukazany w opowiadaniu Dostojewskiego tchnie grozą. Szeregi zmarłych, które przewijają się przed oczami Iwana Iwanycza, przenoszą nas do świata niedostępnego dla żyjących. Rzeczywistość miesza się 
z fantazją, wkraczając w obszary szczątkowo nam tylko znane, niezrozumiałe, pełne niedomówień, a tym samym wzbudzające lęk przed niewiadomym. Właśnie te obszary mieszania się fikcji z rzeczywistością Dostojewski przedstawił w Boboku z właściwą jego pisarstwu mrocznością opisów, wspartą na szczegółowości i drobiazgowości w ukazywaniu postaci i przedmiotów. To opowieść fantastyczna bazująca na motywach życia i śmierci, które zawsze budzą grozę. Jej bohaterowie różnią się od poprzednich tym, że nie mają już wpływu na istniejącą rzeczywistość świata ludzkiego - są poza nim, wdzierają się natomiast do wyobraźni autora jako jego artystyczna wizja.

Wcześniej przedstawione utwory poruszają tematykę grozy i demonizmu w realiach dziewiętnastowiecznej rzeczywistości. To dzieła obfitujące w opisy zła w najrozmaitszych przejawach, „trudna do przeliczenia ilość masek Antychrysta (...)”, jak pisze Wodziński (2018, s. 94). Demoniczne zło znajduje tutaj upodobanie w mądrych, zdrowych i silnych bohaterach, przez co potęguje płynącą z niego grozę. Demoniczność radykalnie przekształca prezentowanych bohaterów, depersonalizuje ich, odczłowiecza. Powtórzmy za Wodzińskim:

miotają się konwulsyjnie, cierpią na częste ataki padaczki, złorzeczą i bluźnią, (...) biegają z siekierami i nożami, zarzynają, strzelają w łeb sobie albo komu innemu, wrzeszczą i lamentują, dyndają na stryczkach, gwałcą małe dziewczynki i torturują małych chłopców, kochają na zabój, (...) targają starców za brody, gryzą gubernatora w ucho, (...) knują i spiskują, (...). Wirują jak chłyści w ekstatycznym stanie... (Wodziński, 2018, s. 61).

Zło demonicznych bohaterów Dostojewskiego poraża nade wszystko dlatego, że ma charakter tajemniczy, ponadludzki, w dużej mierze metafizyczny. Oni zaś jawią się jedynie jako jego uosobienie, wcielenie. I choć są piękni, młodzi i inteligentni, budzą strach, gdyż są zarazem niedookreśleni i niejednoznaczni (Zabukovec, 2013). I jako tacy zdolni są przekształcić się w potwory. Demoniczność postaci Dostojewskiego poraża czytelnika swoim przeklętym pięknem, diabelską pustką widoczną w ich oczach (Kiriłłow, Stawrogin), bezczelnością i wulgaryzmem. Każdy z omówionych tutaj bohaterów twórcy Zbrodni i kary reprezentuje sobą inne oblicze demoniczności: targany wątpliwościami filozoficznymi samobójca Kiriłłow, Stawrogin jako uosobienie czystego zła, wiecznie namawiający innych do czynienia zła Wierchowieński, targane ludzkimi namiętnościami trupy z opowiadania Bobok czy alter ego Iwana Karamazowa - Diabła. Poprzez tę różnorodność pisarz pokazuje, jak wiele masek może przybrać zło, aby doprowadzić do upadku człowieka. Dostojewski, na przykładzie poszczególnych bohaterów, podkreśla, że diabeł czyha na człowieka w każdej minucie jego życia gotowy zaatakować w najmniej 
oczekiwanym momencie. Autor uświadamia czytelnikowi, że walka o ludzką duszę trwa nieustannie i tylko od jednostki zależy, jak ona się skończy. Pisarz bowiem nie potępia wyborów swoich bohaterów, ukazuje ich zmagania ze słabościami i targającymi ich namiętnościami. Podkreśla także, że Bóg gotów jest zawsze wybaczyć, człowiek musi tylko uświadomić sobie ogrom popełnionego zła i okazać skruchę za popełnione czyny.

\section{BibliografiA}

Augustyn, L. (2015). Wielki Inkwizytor a idea rosyjska. Kultura i Wartości, nr $14,51-62$.

Bierdiajew, N. (2002). Stawrogin. W N. Bierdiajew, Smysl tvorczestwa. Moskwa: ACT.

Bierdiajew, M. (2004). Światopogląd Dostojewskiego. Kęty: Wydawnictwo Antyk.

Dostojewski, F. (1976). Aforyzmy, t. I. Warszawa: Państwowy Instytut Wydawniczy.

Dostojewski, F. (1979). Z notatników. Warszawa: Czytelnik.

Dostojewski, F. (2009). Bracia Karamazow. Kraków: Znak.

Dostojewski, F. (2015). Biesy. Kraków: MG.

Evdokimov, P. (1972). Cristo nel pensiero Russo. Roma: Città Nuova.

Evdokimov, P. (2002). Gogol i Dostojewski, czyli zstapienie do otchtani. Bydgoszcz: Homini.

Gogacz, M. (1998). Elementarz metafizyki. Warszawa: Veni.

Grzmot-Bilski, G.J. (2016). Misterium iniquitatis. Bierdiajew i Dostojewski. Folo-Sofija, nr 34 (3/I), 199-218.

Jastrząb, D. (2017). Stawrogin - personifikacja zła. Jezyk. Religia. Tożsamość, 1 (15), 135-144.

Krasucka, K. (2011). Biesy Fiodora Dostojewskiego jako wykład refleksji filozoficznej. Idea - Studia nad struktura i rozwojem pojęć filozoficznych, XXIII, 85-99.

Leatherbarrow, W.J. (2005). A Devil's Vaudeville. The Demonic in Dostoevsky's Major Fiction. Evanston: Northwestern University Press.

Lotman, J.M. (2002). Rol' dualnych modelej w dinamike russkoj kultury. W J.M. Lotman, Istorija i tipologia russkoj kultury. Sankt-Petersburg: SPB.

Łosskij, N.O. (1953). Dostoevskij i ego hristianskoe miroponimanie. New York: Chekchov Publishing House.

Łużny, R. (red.). (1984). Okrutny talent. Dostojewski we wspomnieniach, krytyce i dokumentach. Kraków-Wrocław: Wydawnictwo Literackie.

Michalska-Suchanek, M. (2015). Samobójcy Fiodora Dostojewskiego. Katowice: Wydawnictwo Uniwersytetu Śląskiego.

Miłosz, C. (1985). Ziemia Urlo. Paryż: Instytut Literacki. 
Paci, E. (1980). Zwiazki i znaczenia: eseje wybrane. Warszawa: Czytelnik. Paprocki, H. (2000). Wolność i zło. Więź 497, nr 3, 26-37.

Penke, A. (2004). Chrystus u Fiodora Dostojewskiego na podstawie legendy Wielki inkwizytor. Forum Teologiczne, 5, 131-141.

Perkowska, I. (2006). Natura człowieka w twórczości Dostojewskiego. Acta Universitatis Lodziensis Folia Philosophica, 18, 103-114.

Przebinda, G. O terrorystach-metafizykach u Dostojewskiego. Nieśmiertelność dla herosów. Pozyskano z: http://www.rubl.uj.edu.pl/pracownicy/fiszka. php?os $=01 \_$przebinda\&jed $=$KKSW\&opis $=$przeb_tp11\&w $=1$ (dostęp: 04.03.2021).

Puszkin, A. (1982). Biesy. W: A. Puszkin, Wybór wierszy. Wrocław: Zakład Narodowy im. Ossolińskich, 311-312.

Raźny, A. (2004). Od Oniegina do Stawrogina - przemiana ,zbędnego człowieka” w demona. W W. Kowalczyk i A. Orłowska (red.), Motywy demonologiczne w literaturze i kulturze rosyjskiej XI-XX wieku. Lublin: Wydawnictwo Uniwersytetu Marii Curie-Skłodowskiej, 131-139.

Smaga, J. (2009). Wstęp. W F. Dostojewski, Bracia Karamazow. Kraków: Znak.

Sucharski, T. (2002). Dostojewski Herlinga-Grudzińskiego. Lublin: Wydawnictwo Uniwersytetu Marii Curie-Skłodowskiej.

Szkudlarek, E. (2008). Bobok jest obok. Pozyskano z: http://www.dziennikteatralny.pl/artykuly/bobok-jest-obok.html (dostęp: 08.03.2021).

Wildstein, B. (2015). Cienie moich czasów. Poznań: Zysk i S-ka.

Williams, R. (2008). Dostoevsky. Language, Faith, and Fiction. Waco, Tex.: Baylor University Press.

Wodziński, C. (2018). Trans, Dostojewski, Rosja, czyli o filozofowaniu siekiera. Gdańsk: Fundacja Terytoria Książki.

Zabukovec, U. (2011). „Taka otóż chwilka”. Stan duchowy człowieka a jego percepcja rzeczywistości w powieści Bracia Karamazow F. Dostojewskiego. Studia Gdańskie, t. 29, 377-402.

Zabukovec, U. (2013). Ciało w Biesach - ciało biesów. Komunikacja niewerbalna w powieści Fiodora Dostojewskiego. Kultura Wspótczesna. Teoria, Interpretacje, Praktyka, 4 (79), 183-196.

Agata Kilar - doktor nauk o kulturze i religii, absolwentka filologii polskiej i kulturoznawstwa (spec. rosjoznawstwo) na Uniwersytecie Jagiellońskim. Interesuje się literaturą pozytywizmu i Młodej Polski (w szczególności twórczością Stanisława Wyspiańskiego) oraz kulturą i literaturą rosyjską (twórczość pisarzy rosyjskich XIX w., głównie Dostojewskiego i Tołstoja). 
